\title{
ANALISIS PENGARUH FAKTOR BUDAYA DAN SOSIAL TERHADAP KEPUTUSAN PEMBELIAN SMARTPHONE MEREK SAMSUNG
}

\author{
Muhammad Nur Aminudin \\ Institut Agama Islam Negeri (IAIN) Fattahul Muluk Papua \\ E-mail: kid.shinichi517@gmail.com \\ Muhammad Anang Firdaus \\ Institut Agama Islam Negeri (IAIN) Fattahul Muluk Papua \\ E-mail: anangfirdaus14@gmail.com \\ Ira Eka Pratiwi \\ Institut Agama Islam Negeri (IAIN) Fattahul Muluk Papua \\ E-mail: irax23@gmail.com
}

\begin{abstract}
This study aims to analyze the influence of cultural and social factors on the purchasing decision of Samsung brand smartphones on IAIN Fattahul Muluk Papua Students. This type of research uses quantitative research. The population in this study were students of IAIN Fattahul Muluk Papua. The number of samples obtained was 280 students, consisting of 68 students of the Faculty of Islamic Economics and Business, 64 students of the Faculty of Syariah, and 148 students of the Faculty of Tarbiyah. Data were collected using a questionnaire, while data analysis techniques used is Multiple Linear Regression. This research shows that cultural factors have a positive and significant influence on the purchasing decisions of Samsung brand smartphones, while social factors have a positive but insignificant effect on the purchasing decisions of Samsung brand smartphones. Furthermore, the influence of cultural factors and social factors simultaneously have a positive and significant effect on purchasing decisions Samsung smartphone brand.
\end{abstract}

Keywords: Cultural Factor, Social Factor, Purchasing Decision.

\begin{abstract}
ABSTRAK
Penelitian ini bertujuan untuk menganalisis pengaruh faktor budaya dan sosial terhadap keputusan pembelian smartphone merek Samsung pada Mahasiswa IAIN Fattahul Muluk Papua. Jenis penelitian ini menggunakan penelitian kuantitatif. Populasi dalam penelitian ini adalah Mahasiswa IAIN
\end{abstract}


Fattahul Muluk Papua. Jumlah sampel yang yang diperoleh sebanyak 280 Mahasiswa, yang terdiri dari 68 Mahasiswa fakultas FEBI, 64 Mahasiswa Fakultas Syariah, dan 148 Mahasiswa Fakultas Tarbiyah. Data dikumpulkan menggunakan kuesioner. Teknik analisis data menggunakan Regresi Linier Berganda. Penelitian ini menunjukan bahwa Faktor budaya berpengaruh positif dan signifikan terhadap keputusan pembelian smartphone merek Samsung dan Faktor sosial berpengaruh positif tetapi tidak signifikan terhadap keputusan pembelian smartphone merek Samsung sedangkan pengaruh faktor budaya dan faktor sosial secara simultan atau bersama-sama berpengaruh positif dan signifikan terhadap keputusan pembelian smartphone merek Samsung. Kata kunci: Faktor Budaya, Faktor Sosial, Keputusam Pembelian.

\section{PENDAHULUAN}

Indonesia merupakan salah satu pasar terbesar untuk penjualan smartphone, karena tingkat permintaan untuk kategori smartphone dinegara ini tinggi. terdapat beberapa merek smartphone yang bersaing dalam bisnis ini di Indonesia antara lain: Samsung, Apple, Huawei, Xiaomi, Lenovo dan masih banyak lagi. Keadaan seperti ini menyebabkan persaingan yang ketat antara para kompetitor pada usaha di bidang telekomunikasi.

Salah satu lembaga riset konsumen global canalys menyebutkan Indonesia sebagai pasar ponsel paling cerah di Asia Pasifik dengan pengapalan ponsel pada 2018 meningkat 17,1\% di banding tahun 2017. Disebutkan canalys, tahun 2018 mencetak rekor dengan pengiriman perangkat tertinggi mencapai 38 juta unit. Sedangkan laporan untuk kuartal keempat 2018, total pengiriman ponsel di Indonesia mencapai 9,5 juta unit, dengan pertumbuhan sebesar 8,6\% dari tahun ke tahun. Merek samsung menjadi smartphone terlaris di Indonesia untuk kuartal ke empat 2018 mengungguli merek-merek asal Cina. Samsung tumbuh 21,5\% dari tahun ke tahun dengan penguasaan pasar sebesar 25,4\%. Dan posisi kedua ditempati oleh merek asal Cina yaitu Xiomi yang mencatatkan sejarah baru. Pada kuartal keempat Xiomi mampu mencatatkan pertumbuhan yoy tertinggi hingga 139,4\% merek asal Cina ini mampu menguasi market share sebanyak 20,5\%. Berbeda dengan Xiomi, smartphone merek Oppo justru dalam tekanan karena membukukan pertumbuhan kuartal paling lama sejak quartal tiga 2017. Secara YoY, oppo hanya naik sebesar 0,8\% dengan penguasaan pasar sebesar 19,5\% hingga membuatnya beraada di posisi ketiga. Lalu di urutan keempat masih ditempati oleh merek asal Cina lainnya yaitu Vivo. Vivo hanya bisa menguasai pasar sebesar15,9\% dan posisi kelima ada Advan, brand nasional ini mampu bertahan di market share sebesar 4,1\%. (Agus Tri Haryanto, 2019).

Brand image (citra merek) adalah persepsi dan keyakinan yang dilakukan oleh konsumen, seperti tercemin dalam asosiasi yang terjadi dalam memori 
konsumen. Apabila perusahaan berhasil menciptakan image yang positif dan kuat, maka hasilnya akan dirasakan dalam jangka panjang terlebih jika mampu memeliharanya yaitu dengan selalu konsisten memberikan dan memenuhi janji yang melekat pada citra yang sengaja dibentuk tersebut. Merek yang memiliki image yang baik akan memicu konsumen dalam melakukan word of mouth dikarenakan konsumen percaya terhadap merek. (Hutami permatasari, 2016).

Pasar sebagai pihak yang menawarkan berbagai produk kepada konsumen harus dapat menganalisis faktor-faktor yang mempengaruhi konsumen dalam pembelian. Mengetahui presepsi konsumen dalam menilai suatu produk dalam pembelian sehingga pasar dapat merancang strategi pemasaran yang sesuai dengan keinginan konsumen.

Mengetahui dasar konsumen melakukan pembelian. Tentunya akan memudahkan dalam hal penentuan strategi yang tepat, sehingga keinginan dan kebutuhan konsumen yang akan terpenuhi. Perilaku konsumen didefinisikan sebagai studi tentang unit pembelian (buying units) dan proses pertukaran yang melibatkan porelahan, konsumsi dan pembuangan barang, jasa, pengalaman, dan ide-ide. (Jhon c. mowen dan Michael monir, 2002).

Pemahaman tentang konsumen dan proses konsumsi akan menghasilkan sejumlah manfaat yang diantaranya adalah kemampuan untuk membantu para manejer mengambil keputusan, memberikan para peneliti pemasaran pengetahuan dasar ketika menganalisis konsumen, membantu legeslatif Negara dalam pembuatan peraturan menciptakan hukum dan peraturan yang berhubungan dengan pembelian dan penjualan barang atau jasa, dan membantu konsumen menengah dalam pengambilan keputusan yang lebih baik. Lebih lanjut mempelajari perilaku konsumen akan memperdalam pemahaman tentang faktorfaktor psikologis, sosial, pribadi dan kebudayaan.

Menurut Philip Kotler dan Gary Armstrong (Sunarto, 2018) perilaku konsumen dapat dipengaruhi oleh beberapa faktor, diantaranya: 1. Faktor budaya meliputi: a). Budaya merupakan faktor penentu keinginan dan perilaku seseorang yang paling mendasar. Pemasar selalu berusaha mengenali pergeseran budaya untuk menemukan produk baru yang diinginkan. b). Sub-Budaya merupakan identifikasi dan sosialisasi yang khas untuk perilaku anggotanya. Dapat dibedakan adanya empat macam sub-budaya, yaitu: kelompok kebangsaan, kelompok keagamaan, kelompok ras dan daerah geografis. c). Kelas Sosial, merupakan sebuahkelompok yang relatif sejenis dan bertahan dalam sebuah masyarakat, yang tersusun dalam sebuah urutan jenjang, dan para anggota dalam setiap jenjang memiliki nilai, minat dan tingkah laku yang sama. 2. Faktor Sosial yang meliputi: a). Kelompok, Sikap dan perilaku individudipengaruhi oleh banyak kelompok kecil. Kelompok yang berpengaruh langsung terhadap individu disebut kelompok keanggotaan. Kelompok referensi, tampil sebagai pengacuan langsung atau tidak 
langsung dalam membentuk sikap dan perilaku seseorang. Kelompok aspirasional di nama mereka tidak termasuk anggota akan tetapi mempunyai keinginan untuk berpartisipasi / mengikuti. Kelompok biasanya mempunyai pemimpin opini yaitu orang dalam kelompok referensi yang karena keterampilan, pengetahuan, kepribadian, atau karakteristik khusus lainnya mempunyai pengaruh terhadap anggota yang lain. b). Keluarga, Anggota keluarga sangat mempengaruhi perilaku pembeli. Keluarga masih merupakan organisasi pembelian konsumen terpenting dalam masyarakat. c). Peran dan Status, Masing-masing peran membawa status yang mencerminkan penghargaan umum yang diberikan kepada peran oleh masyarakat. Peran dan status bukan merupakan variabel yang konstan. Banyak profesional pemasaran dan penjualan membuat kekeliruan penilaian yang terkait dengan peran dan status calon pelanggan.

Berdasarkan uraian diatas faktor budaya merupakan faktor penentu keinginan dan perilaku seseorang yang paling mendasar dalam mengkonsumsi suatu barang. Sementara itu kelompok sosial dijelaskan juga memiliki pengaruh langsung terhadap perilaku konsumsi seseorang. Dengan demikian, dua faktor ini yang menjadi kajian utama yang akan dianalisis oleh peneliti dengan judul penelitian "Analisis Faktor-Faktor yang Nempengaruhi Perilaku Konsumen Terhadap Keputusan Pembelian Handphone Merek Samsung pada Mahasiswa IAIN Fathul Muluk Papua.

\section{KAJIAN LITERATUR}

\section{Konsep Pemasaran}

Pemasaran adalah proses sosial yang dengan proses itu individu dan kelompok mendapatkan apa yang mereka butuhkan dan inginkan dengan menciptakan, menawarkan, dan secara bebas mentukarkan produk dan jasa yang bernilai dengan pihak lain. Sedangkan menurut asosiasi pemasaran amerika mendefinisikaan pemasaran adalah proses perencanaan dan pelaksanaan pemikiran, penetapan harga, promosi, dan penyaluran gagasan, barang, dan jasa untuk menciptakan pertukaran yang memenuhi sasaran-sasaran individu dan organisasi (Kotler, 2005). Jadi pemasaran adalah suatu usaha untuk merencanakan, mengimplementasikan yang terdiri manajemen dari kegiatan mengorganisasikan, mengarahkan, dan mengkoordinir serta mengawasi atau mengendalikan kegiatan pemasaran dalam suatu organisasi agar tercapai tujuan organisasi secara efisien dan efektif.

\section{Perilaku Konsumen}

Menurut American association mendefinisikan perilaku konsumen sebagai interaksi dinamis antara pengaruh dan kognisi, perilaku, dan kejadian disekitar kita dimana manusia melakukan aspek pertukaran dalam hidup mereka (Peter dan Olson, 1999). Paling tidak ada tiga ide penting dalam definisi di atas pertama perilaku konsumen adalah dinamis, ini berarti bahwa seorang konsumen, group konsumen, serta masayarakat luas selalu berubah dan bergerak sepanjang waktu. 
Yang kedua, keterlibata antar pengaruh dan kognisi, perilaku dan kejadian di sekitar. Ini berarti bahwa untuk memahami konsumen dan mengembangkan stategi pemasaran yang tepat kita harus memahami apa yang mereka pikirkan dan mereka rasakan, apa yang mereka lalukan dan apa serta dimana yang mempengaruhi serta di pengaruhi oleh apa yang dipikirkan, diarasa dan dilakukan oleh konsumen. Yang ketiga pertukaran, diantara individu hal ini membuat devinisi perilaku konsumen tetap konsisten dengan devinisi pemasaran yang sejauh ini menekankan pertukaran.

Perilaku konsumen adalah studi tentang bagaimana individu, kelompok, dan organisasi memilih, membel, menggunakan, dan bagaimana barang, jasa, ide atau pengalaman untuk memuaskan kebutuhan dan keinginan mereka. Perilaku pembelian konsumen di pengaruhi oleh faktor budaya, fator social, faktor pribadi, dan faktor psikologis. Faktor budaya memberikan pengaruh yang paling luas dan dalam. (Kotler dan Keller, 2008).

\section{Faktor-faktor yang Mempengaruhi Perilaku Konsumen}

Peran faktor-faktor tersebut berbeda untuk produk yang berbeda. Dengan kata lain, ada faktor yang dominan untuk pembelian suatu produk sementara produk lain kurang berpengaruh, beberapa faktor tersebut menyatu dalam pemikiran konsumen, diolahnya sedemikian rupa sampai akhirnya ia membuat keputusan pembelian serta respon yang ia berikan terhadap faktor-faktor pendorong tersebut berupa tindakan membeli atau tidak membeli produk yang ditawarkan.

Ada dua faktor yang mempengauhi perilaku konsumen dalam pembelian yaitu: 1. Faktor Budaya yang meliputi, a). Budaya, budaya adalah kumpulan tentang keyakinan, nilai, adat yang berfungsi untuk mengarahkan perilaku konsumen di anggota masyarakat tertentu (Kotler, 2005). b). Sub-budaya, yang mencakup kebangsaan, agama, kelompok ras, dan wilayah geografis. Ketika subkultur menjadi besar dan cukup makmur, para perusahaan sering merancang progam pemasaran secara khusus untuk melayani mereka. Progam-progam tersebut dikenal sebagai pemasaran keanekaragaman. (Kotler dan Keller, 2008). c). Kelas sosial, kelas sosial adalah strata atau susunan atau lapisan yang ada dalam masyarakat (Noviyanti, 2019). Kelas sosial menunjukan bagaimana kedudukan setiap masyarakat per tingkatan. 2. Faktor sosial yang meliputi, a). Kelompok keanggotaan seperti keluarga, teman, dan tetangga. b). Keluarga yang merupakan organisasi pembelian konsumen yang paling penting dalam masyarakat. c). Peran dan status, orang-orang lebih memilih produk yang dapat mengkomunikasikan peran dan status mereka dimasyarakat. 


\section{Keputusan Pembelian}

Keputusan sebagai pemilihan suatu tindakan dari dua pilihan alternatif atau lebih. Dan menurut Setiadi mendefinisikan bahwa inti dari pengambilan keputusan konsumen adalah proses pengintegrasian yang mengombinasikan pengetahuan untuk mengevaluasi dua perilaku alternatif atau lebih, dan memilih salah satu diantaranya. (Rita, 2018). Hasil dari proses pengintegrasian ini adlah suatu pilihan yang disajikan secara kognitif sebagai keinginan berperilaku. keputusan pembelian konsumen adalah membeli merek yang paling dikehendaki. Tetapi dua faktor akan berada antara tujuan dan keputusan pembelian. Faktor pertama adlah sikap orang lain. Dan faktor kedua adalah keadaan tak terduga (Kotler dan Keller, 2008).

\section{Proses Keputusan Pembelian}

Ada lima tahap yang dilalui konsumen dalam proses pembelian (Kotler, 2007), yaitu 1. Pengenalan masalah, proses pembelian dimulai ketika pembeli mengenali masalah atau kebutuhannya. Para pemasar perlu mengidentifikasi keadaan yang memicu kebutuhan tertentu dengan mengumpulkan sejumlah informasi dari konsumen. 2. Pencarian informasi, Konsumen yang terangsang kebutuhannya akan terdorong untuk mencari informasi yang lebih banyak. 3 . Evaluasi alternatife, di fase ini konsumen akan lebih selektif dalam menentukan keputusan pembeliannya dan dalam tahap evaluasi para konsumen membentuk preferensi atas merek-merek yang ada didalam kumpulan pilihan. Konsumen tersebut juga bisa membentuk niat untuk membeli merek yang paling disukai. 4 . Keputusan pembelian, setelah memalui tahap evaluasi konsumen akan menentukan prodak atau barang yang sesui dengan yang ia sukai. 5. Perilaku pasca pembelian, Pada tahap ini, konnsumen mengevaluasi apakah alterative yang dipiilih akan memenuhi kebutuhan dan harapan segera sesudah digunakan. Setelah mengkonsumsi alternatif yang dipilih, konsumen kembali melakukan evaluasi terhadap barang dan jasa yang dikonsumsinya. Jika kinerja barang atau jasa yang digunakannya tidak sesuai dengan harapannya, maka konsumen tersebut akan merasa tidak puas.

\section{Kerangka Berpikir}

Berdasarkan landasan teori di atas, faktor budaya dan faktor sosial adalah faktor-faktor yang mempengaruhi perilaku konsumen dalam keputusan pembelian handphone Samsung. Variabel bebas (Independent Variable) yaitu faktor Budaya (X1), faktor Sosial (X2), sedangkan variabel terikat (Dependent Variable) yaitu keputusan pembelian (Y). Maka dapat digambarkan dalam bentuk kerangka pikir yaitu sebagai berikut: 
Gambar : 2.8.1 Kerangka Berpikir

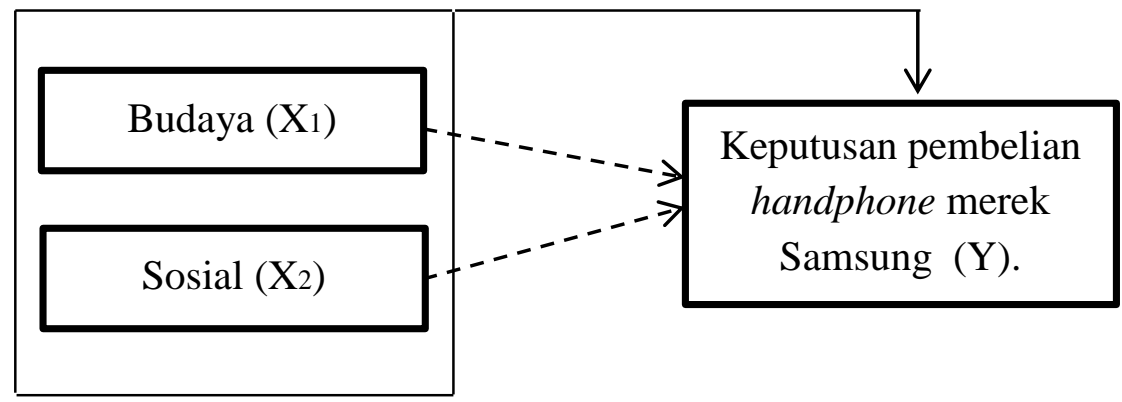

\section{METODE PENELITIAN}

Jenis penelitian yang penulis gunakan menggunakan jenis penelitian kuantitatif. Penelitian kuantitatif adalah sebuah penelitian yang bertujuan menggambarkan fenomene atau gejala sosial secara kuantitatif atau menganalisis bagaimana fenomena atau gejala sosial yang terjadi dimasyarakat saling berhubungan satu sama lain. (Sudaryono, 2017) Metode penelitian yang digunakan adalah penelitian deskriptif asosiatif. Penelitian deskriptif adalah penelitian yang dilakukan untuk mengetahui nilai variabel mandiri, baik satu variabel atau lebih (independen) tanpamembuat perbandingan, atau menghubungkan antara variabel satu dengan variabel yang lain (Darmawan, 2013). Penelitian asosiatif yaitu penelitian yang bertujuan untuk mengetahui pengaruh ataupun juga hubungan antara dua variabel atau lebih. Penelitian ini mempunyai tingkatan tertinggi dibandingkan dengan diskriptif dan komparatif karena dengan penelitian ini dapat dibangun suatu teori yang dapat berfungsi unguk menjelaskan, meramalkan dan mengontrol suatu gejala. (Widisudharta, 2019).

Lokasi penelitian ini dilaksanakan di Papua, pada kampus IAIN (Institut Agama Islam Negeri) Fathul Muluk Papua. Yang berlokasi di Jl. Merah Putih Buper Waena Distrik Heram Kota Jayapura.

\section{Jenis dan Sumber Data}

Jenis data yang digunakan dalam penelitian meliputi hal-hal berikut. Data primer, yaitu data yang diperoleh secara langsung dari narasumber atau responden.

1. Data skunder, yaitu data yang diperoleh dari dokumen atau publikasi atau laporan penelitian dari dinas, instansi maupun sumber data lainya yang menunjang.

\section{Populasi dan Sampel}

Menurut Kurniawan, Populasi adalah wilayah generelasasi yang terdiri dari objek atau subjek yang memunyai kualitas dan karakteristik tertentu yang ditetapkan oleh peneliti untuk dipelajari kemudian di tarik kesimpulannya 
(Sudaryono, 2017). Dalam penelitian ini yang menjadi populasi adalah konsumen yang telah membeli handphone merek Samsung di Institut Agama Islam Negeri (IAIN) Fathul Muluk papua.

Pada penelitian ini, penulis menjadikan mahasiswa pada Kampus IAIN papua sebagai populasi. Jumlah populasinya pada tahun 2018-2019 semester ganjil sebanyak 928 mahasiswa yang terdiri dari Fakultas Ekonomi dan Bisnis Islam, Fakultas Syariah, dan Fakultas Tarbiyah dengan perbandingan jumlah mahasiswa masing-masing fakultas adalah $224: 212: 492$.

Sampel adalah sebagaian dari pupolasi yang karakteristeknya hendak diselidiki, dan dianggap bisa mewakili keseluruhan populasi (jumlah lebih sedikit dari pada jumlah populasinya. Dalam hal ini peneliti menggunakan rumus yang dikemukakan oleh slovin untuk menghitung jumlah sampel, (Umar, 2003) sebagai berikut:

$$
\mathrm{n}=\frac{N}{1+N(e)^{2}}
$$

Keterangan :

$\mathrm{N}=$ Jumlah Populasi

$\mathrm{n}=$ Jumlah Sampel

$\mathrm{e}=$ Tingkat Kesalahan $(5 \%)$

$$
\text { jadi } \begin{aligned}
\mathrm{n} & =\frac{N}{1+N(e)^{2}}=\frac{928}{1+928(5 \%)^{2}} \\
& =\frac{928}{1+928(0,0025)} \\
& \mathrm{n}=279,5 \text { atau di bulatkan menjadi } 280 \text { responden. }
\end{aligned}
$$

Dari jumlah sampel tersebut kemudian ditentukan jumlah ssampel untuk masing-masing jurusan sesuai dengan rasio perbandingan jumlah mahasiswa IAIN Papua pada data tahun 2018-2019 sebagai berikut:

Fakultas Ekonomi dan Bisnis $\mathrm{n}=\frac{224}{928} \times 280$ orang $=67,5=68$ responden

Fakultas Syariah $\mathrm{n}=\frac{212}{928} \times 280$ orang $=63,9=64$ responden

Fakultas Tarbiyah

$$
\mathrm{n}=\frac{492}{9 \underline{28}} \times 280 \text { orang }=\quad 148 \text { responden }
$$

Total

$$
=280 \text { responden }
$$

Adapun teknik pengambilan sampel yang digunakan yaitu purposive sampling. Purposive sampling yaitu responden yang terpilih menjadi anggota sampel atas dasar pertimbangan peneliti sendiri.

\section{Teknik Pengumpulan Data}

1. Kuesioner

Kuesioner, merupakan teknik pengumpulan data yang dilakukan dengan cara memberi seperangkat pertanyaan atau pernyataan tertulis kepada responden 
untuk dijawab (Rahmat, 2013). Kuesioner merupakan teknik pengumpulan data yang efisien apabila peneliti mengetahui variabel yang akan diukur dan hal-hal yang bisa diharpakan dari responden. Selain itu, kuesioner juga digunakan untuk jumlah responden yang cukup besar dan tersebar diwilayah yang luas. Kuesioner dapat berupa pertanyaan ata pernyataan tertutup ataupun terbuka, yang diberikan kepada responden secara langsung atau dikiri melalui pos, atau internet.

2. Observasi

Observasi adalah cara yang sangat efektif untuk mengetahui apa yang dilakukan orang dalam konteks tertentu, pola prutinitas dan pola interaksi dari kehidupan mereka sehari-hari (Anggito dan Setiawan, 2018). Metode penelitian observasional dapat memberikan pemahaman tentang apa yang terjadi dalam hubungan antara penyedia layanan dan pengguna, atau dalam keluarga, komite, unit lingkungan atau tempat tinggal, sebuah organisasi besar atau sebuah komonitas.

\section{Uji Instrumen Penelitian}

\section{Uji Validitas}

Validitas adalah tingkat keandalah dan kesahihan alat ukur yang digunakan. Intrumen dikatakan valid berarti menunjukkan alat ukur yang dipergunakan untuk mendapatkan data itu valid atau dapat digunakan untuk mengukur apa yang seharusnya di ukur (Sugiyono, 2007). Pengujian ini menggunakan tingkat signfikansi sebesar 5\%. Adapun kreteria penilaian uji validitas adalah:

a) Apabila $\mathrm{r}_{\text {hitung }}>\mathrm{r}_{\text {tabel }}$ (pada taraf signifikansi 5\%), maka dapat dikatakan item kuesioner tersebut valid.

b) Apabila $\mathrm{r}_{\text {hitung }}<\mathrm{r}$ tabel (pada taraf signifikansi 5\%), maka dapat dikatakan item kuesioner tersebut tidak valid.

2. Uji Realibilitas

Suatu instrumen dikatakan reliabel apabila hasil pengukuran dengan instrumen tersebut adalah sama jika sekiranya pengukuran tersebut dilakukan pada orang yang sama pada waktu yang berlainan. Realibilitas menyangkut masalah ketepatan ukur. Disini pengukurannya hanya sekali dan kemudian hasilnya dibandingkan dengan pertanyaan lain atau mengukur korelasi antara jawaban pertanyaan. Alat untuk mengukur reliabilitas adalah Alpha Cronbach. Menurut Ghozali, suatu variabel dikatakan reliabel, apabila:

a) Hasil Alpha Cronbach > 0,6 maka bisa dikatakan reliabel

b) Hasil Alpha Cronbach < 0,6 maka bisa dikatakan tidak reliabel 


\section{Metode Analisis}

Metode analisis datayang digunakan dalam penelitian ini adalah analisis regresi berganda. Regresi berganda berguna untuk membuktikan ada atau tidaknya hubungan antara dua buah veriabel bebas $(\mathrm{X})$ atau lebih dengan sebuah variabel terikat (Y) (Hartono, 2013). Metode ini dipilih penulis untuk mengetahui seberapa besar pengaruh keberadaan variabel budaya $\left(\mathrm{X}_{1}\right)$ dan variabel $\left(\mathrm{X}_{2}\right)$ terhadap keputusan pembelian (Y). Adapun rumus yang digunakan adalah sebagai berikut:

$$
\mathrm{Y}=\mathrm{a}+\mathrm{b}_{1} \mathrm{X}_{1}+\mathrm{b}_{2} \mathrm{X}_{2}+\mathrm{e}
$$

Keterangan:

$\mathrm{Y}=$ Keputusan pembelian

$\mathrm{X}_{1}=$ Budaya

$\mathrm{X}_{2}=$ Sosial

$\mathrm{a}=$ konstanta (nilai pada saat nol)

$\mathrm{b}=$ Koefisien regresi

$\mathrm{e}=$ Eror atau residu

\section{Uji Asumsi Klasik}

1. Uji Asumsi Klasik Multikolinieritas

Uji asumsi klasik ini diterapkan untuk analisis regresi berganda, Untuk mengetahui ada tidaknya multikolinieritas dalam model regresi dapat dilihat dari tolerance value atau variance inflation factor (VIF). Sebagai dasar acuannya dapat disimpulkan (Ghozhali, 2011):

a. jika nilai tolerance $>0,10$ dan nilai VIF $<10,00$ maka artinya tidak terjadi multikolinieritas.

b. Jika nilai tolerance $<0,10$ dan nilai VIF $>10,00$ maka artinya telah terjadi multikolinieritas.

2. Uji Asumsi Klasik Heteroskedastisitas

Uji heteroskedastisitas dilakukan untuk mengetahui apakah dalam sebuah model regresi terjadi ketidaksamaan varians dari residual suatu pengamatan ke pengamatan lain. Sehingga apabila tidak terjadi heteroskedastisitas maka regresi dapat dikatakan baik (Husein, 2008).

3. Uji Asumsi Klasik Normalitas

Uji normalitas dilakukan untuk mengetahui apakah variabel dependen, independen atau keduanya berdistribusi normal, mendekati normal atau tidak normal (Husein, 2008).

\section{Pengujian Hipotesis}

a. Statistik Uji t 
Uji statistik t digunakan untuk mengukur seberapa jauh pengaruh variabel bebas secara parsial dalam menerangkan variasi variabel terikat.

b. Statistik Uji F

Uji statistik f dalam analisis regresi linear berganda digunakan untuk mengukur seberapa jauh pengaruh variabel bebas secara secara bersama-sama dalam menerangkan variabel terikat.

\section{HASIL DAN PEMBAHASAN}

Sampel dalam penelitian ini sebanyak 280 responden yang terdiri dari mahasiswa Fakultas Ekonomi dan Bisnis Islam, Fakultas Syariah, dan Fakultas Tarbiyah IAIN Fathul Muluk Papua yang menggunakan smartphone merek Samsung.

\section{Uji Validitas dan Reliabilitas}

Tabel 1. Hasil Penelitian

\begin{tabular}{|c|c|c|c|c|}
\hline No & Item & r hitung & r tabel & Validitas \\
\hline 1 & $\mathrm{X} 1$ & 0,441 & 0,306 & Valid \\
\hline 2 & $\mathrm{X} 2$ & 0,569 & 0,306 & Valid \\
\hline 3 & $\mathrm{X} 3$ & 0,524 & 0,306 & Valid \\
\hline 4 & $\mathrm{X} 4$ & 0,502 & 0,306 & Valid \\
\hline 5 & $\mathrm{X} 5$ & 0,564 & 0,306 & Valid \\
\hline 6 & $\mathrm{X} 6$ & 0,681 & 0,306 & Valid \\
\hline 7 & $\mathrm{X} 7$ & 0,278 & 0,306 & Tidak Valid \\
\hline 8 & $\mathrm{X} 8$ & $-0,020$ & 0,306 & Tidak Valid \\
\hline 9 & $\mathrm{X} 9$ & 0,557 & 0,306 & Valid \\
\hline 10 & $\mathrm{X} 10$ & 0,308 & 0,306 & Valid \\
\hline
\end{tabular}

Sumber: Data Diolah, 2019

Berdasarkan tabel diatas dimana skor item pernyataan pertama (x1) sampai dengan keenam (x6) dinyatakan valid karena $r$ hitung lebih besar dari $r$ tabel yaitu 0,306 sedangkan item pernyataan ke tujuh (x7) dan delapan (x8) dinyatakan tidak valid karena $r$ hitung item ke tujuh 0,278 dan kedelapan 0,020 lebih kecil dari 0,306 $\mathrm{r}$ tabel dan item pernyataan ke sembilan (x9) dan (x10) dinyatakan valid karna lebih dari 0,306 $\mathrm{r}$ tabel. Oleh karena itu item pernyataan ke 7 dan 8 dihapus dari kuesioner karena tidak valid.

Berdasarkan hasil pengolahan data menggunakan SPSS Cronbach Alpha untuk variabel budaya (X1), variabel sosial (X2), dan variabel keputusan pembelian smartphone merek samsung (Y) yang dapat dilihat pada tabel berikut ini: 
Tabel 2. Uji Reliabilitas

\section{Reliability Statistics}

\begin{tabular}{|c|c|}
\hline $\begin{array}{c}\text { Cronbach's } \\
\text { Alpha }\end{array}$ & N of Items \\
\hline .652 & 8 \\
\hline
\end{tabular}

Sumber: Data Diolah, 2019

Berdasarkan tabel diatas dinyatakan Reliabel karena Cronbach Alpha yang dihasilkan lebih besar dari 0,5 .

\section{Uji Asumsi Klasik}

1. Uji Normalitas

Tabel 3 Hasil Uji Normalitas

One-Sample Kolmogorov-Smirnov Test

\begin{tabular}{|ll|r|}
\hline & & $\begin{array}{r}\text { Unstandardiz } \\
\text { ed Residual }\end{array}$ \\
\hline $\mathrm{N}$ & Mean & 280 \\
Normal Parameters & a & .0000000 \\
Most Extreme & Std. Deviation & 1.58179809 \\
Differences & Absolute & .042 \\
& Positive & .042 \\
Kolmogorov-Smirnov Z & Negative & -.036 \\
Asymp. Sig. (2-tailed) & .708 \\
\hline
\end{tabular}

a. Test distribution is Normal.

Sumber: Data Diolah, 2019

Hasil pengujian statistik one sampel Kolmogorov-smirnov diatas menunjukan bagian sig. dengan nilai sebesar 0,698, artinya nilai tersebut lebih besar dari 0,05 sehingga dapat disimpulkan bahwa nilai residual berdistribusi normal atau memenuhi syarat uji normalitas. 
2. Uji Multikolinieritas

Tabel 4 Hasil Uji Multikolinieritas.

\begin{tabular}{|c|c|c|c|}
\hline Model & Tolerance & VIF & Asumsi multikolonieritas \\
\hline (constant) & & & \\
$\mathrm{X}_{1}$ & 0,928 & 1,078 & Tidak terjadi multikolinieritas \\
$\mathrm{X}_{2}$ & 0,928 & 1,078 & Tidak terjadi multikolinieritas \\
& & & \\
\hline
\end{tabular}

Sumber: Data Diolah, 2019

Berdasarkan tabel diatas maka dapat dilihat bahwa nilai VIF untuk semua variabel independen tidak lebih dari 10,00 dan nilai tolerance semua variabel lebih besar dari 0,10, berdasarkan hasil tersebut dapat ditarik kesimpulan bahwa semua variabel bebas yang terdiri dari faktor budaya dan faktor sosial tidak terjadi multikolinieritas.

\section{Uji Heteroskedastisitas}

Gambar 1 Uji Heteroskedastisitas

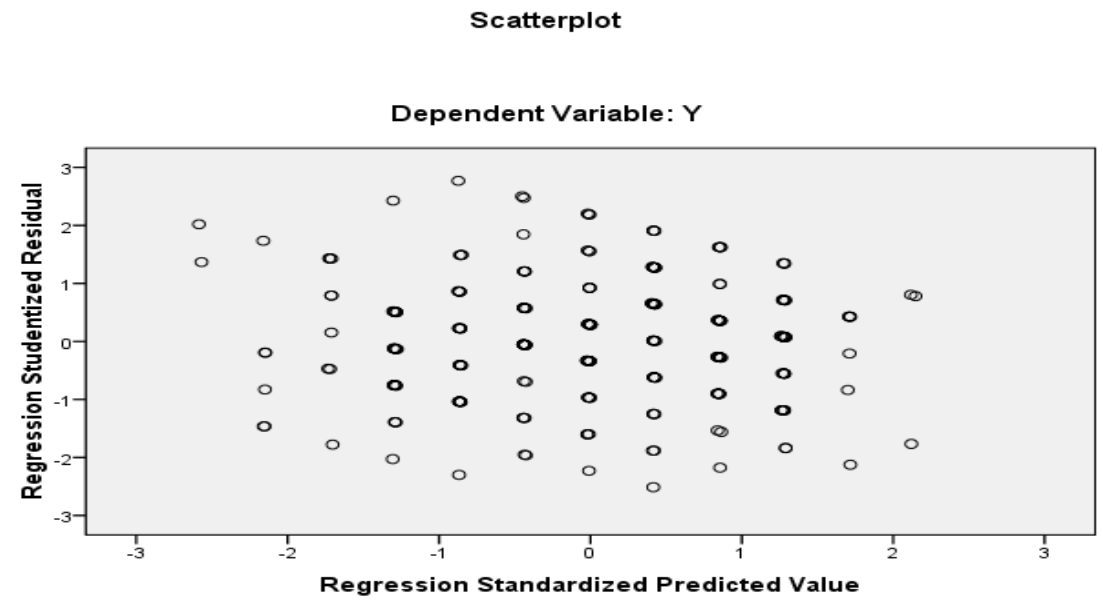

Sumber: Data Diolah, 2019

Berdasarkan hasil pengeolahan data di atas, didapatkan titik-titik menyebar dibawah dan di atas sumbu Y, dan tidak mempunyai pola yang teratur, jadi kesimpulannya variabel bebas tidak terjadi heteroskedastisitas atau bersifat homoskedastisitas. 


\section{Uji Regresi Berganda}

1. Uji Determinasi

Tabel 5 Hasil Uji Determinasi $\left(\mathrm{R}^{2}\right)$

Model Summaryb

\begin{tabular}{|l|r|r|r|r|r|}
\hline Model & \multicolumn{1}{|c|}{$\mathrm{R}$} & R Square & \multicolumn{1}{c|}{$\begin{array}{c}\text { Adjusted R } \\
\text { Square }\end{array}$} & $\begin{array}{c}\text { Std. Error of the } \\
\text { Estimate }\end{array}$ & Durbin-Watson \\
\hline 1 & $.550^{\mathrm{a}}$ & .303 & .298 & 1.587 & 1.466 \\
\hline
\end{tabular}

a. Predictors: (Constant), SOSIAL, BUDAYA

b. Dependent Variable: KEPUTUSAN

Berdasarkan tabel diatas diperoleh angka $\mathrm{R}^{2}(\mathrm{R}$ square) sebesar 0,303 atau $30,3 \%$, hal ini menunjukan bahwa persentase pengaruh faktor budaya dan sosial terhadap keputusan pembelian smartphone merek Samsung yang dilakukan oleh mahasiswa IAIN Fathul Muluk Papua sebesar 30,3\%, sisanya 69,7\% dapat dijelaskan atau dipengaruhi oleh faktor lain.

2. Uji t (Parsial)

Tabel 6 Hasil Uji t

Coefficients $^{\mathrm{a}}$

\begin{tabular}{|c|c|c|c|c|c|c|}
\hline \multirow{2}{*}{\multicolumn{2}{|c|}{ Model }} & \multicolumn{2}{|c|}{ Unstandardized Coefficients } & \multirow{2}{*}{$\begin{array}{c}\begin{array}{c}\text { Standardized } \\
\text { Coefficients }\end{array} \\
\text { Beta }\end{array}$} & \multirow[b]{2}{*}{$\mathrm{t}$} & \multirow[b]{2}{*}{ Sig. } \\
\hline & & B & Std. Error & & & \\
\hline \multirow[t]{3}{*}{1} & (Constant) & 2.052 & .475 & & 4.321 & .000 \\
\hline & BUDAYA & .446 & .042 & .549 & 10.547 & .000 \\
\hline & SOSIAL & .003 & .039 & .004 & .074 & .941 \\
\hline
\end{tabular}

a. Dependent Variable: KEPUTUSAN

Sumber : Data Diolah, 2019

a. Variabel Kebudayaan

Dari tabel diatas menunjukan bahwa nilai sig. variabel kebudayan sebesar 0,000 atau $0 \%<0,05$ itu artinya variabel kebudayaan berpengaruh positif dan signifikan terhadap keputusan pembelian smartphone merek Samsung.

b. Variabel sosial

Dari tabel diatas menunjukan bahwa nilai sig. variabel sosial sebesar 0,941 atau 94,1\% $>0,05$ itu artinya variabel kebudayaan berpengaruh secara positif dan tidak signifikan terhadap keputusan pembelian smartphone merek Samsung. 
3. Uji f (Simultan)

Tabel 7 Hasil Uji f

ANOVA ${ }^{b}$

\begin{tabular}{|ll|r|r|r|r|r|}
\hline \multicolumn{2}{|l|}{ Model } & \multicolumn{1}{|c|}{$\begin{array}{c}\text { Sum of } \\
\text { Squares }\end{array}$} & Df & Mean Square & F & Sig. \\
\hline 1 & Regression & 303.404 & 2 & 151.702 & 60.196 & $.000^{\mathrm{a}}$ \\
& Residual & 698.082 & 277 & 2.520 & & \\
& Total & 1001.486 & 279 & & & \\
\hline
\end{tabular}

a. Predictors: (Constant),SOSIAL,BUDAYA

b. Dependent Variable: KEPUTUSAN

Sumber: Data Diolah, 2019

Berdasarkan hasil regresi berganda dari tabel diatas menunjukan nilai signifikan $0,000<0,05$ maka perhitungan tersebut menunjukan bahwa variabel budaya dan sosial secara bersama-sama mempunyai pengaruh yang positif dan signifikan terhadap variabel keputusan pembelian smartphone merek Samsung.

\section{Pembahasan}

Berdasarkan hasil analisis di atas, maka akan dilakukan pembahasan yang memberikan beberapa informasi secara rinci tentang hasil penelitian serta bagaimana pengaruh masing-masing variabel terhadap variabel lainnya. Variabel bebas dalam penelitian ini yaitu faktor budaya $\left(\mathrm{X}_{1}\right)$ dan faktor sosial $\left(\mathrm{X}_{2}\right)$ terhadap keputusan pembelian smartphone merek Samsung (Y). Pengujian hipotesis antara variabel bebas dan terikat dilakukan melalui hasil analisis SPSS selanjutnya akan dilakukan pembahasan terhadap msing-masing hpotesis sebagai berikut:

1. Pengaruh faktor budaya $\left(\mathrm{X}_{1}\right)$ terhadap keputusan pemebelian $(\mathrm{Y})$ secara parsial.

Berdasarkan output coefficient uji t, diperoleh nilai signifikan 0,000 lebih kecil dari 0,05 yang artinya bahwa faktor budaya $\left(\mathrm{X}_{1}\right)$ berpengaruh positif dan signifikan terhadap keputusan pembeilan smartphone merek Samsung (Y), sehingga Ha diterima yaitu faktor budaya berpengaruh secara positif dan signifikan terhadap keputusan pembelian smartphone merek Samsung.

Berdasarakan hasil kuesioner, masih banyak mahasiswa IAIN Fathul Muluk yang membeli smartphone merek samsung karena dipengaruhi oleh faktor budaya. Misalnya karena melihat perkembangan smartphone yang sering meluncurkan prodak barunya, sehingga menumbuhkan rasa ingin tahu dan tertarik untuk membeli smartphone merek Samsung, hal ini juga di dukung oleh teori 
Kotler yang menyebutkan bahwa faktor budaya menjadi faktor yang paling dominan dan luas dalam mempengaruhi keputusan pembelian. karena budaya merupakan kumpulan nilai-nilai dasar, persepsi, keinginan dan perilaku yang sering dipelajari oleh seseorang dalam mementukan keputusan pembelian dan penentu keinginan.

Adapun penelitian ilmiah yang dilakukan oleh Ikko Julianda dan Eka Komalasari, dengan judul penelitian "Faktor-faktor yang Mempengaruhi Konsumen Dalam Pembelian Produk Smartphone Samsung" hasil penelitian menunjunkan bahwa faktor budaya dan faktor sosial mempengaruhi keputusan pembelian smarphone merek Samsung, dan faktor yang paling dominan atau kuat untuk mempengaruhi keputusan pembelian smartphone merek Samsung adalah faktor budaya. Penelitian ini sejalan dengan penelitian ini yang dimana faktor budaya adalah faktor yang paling dominan dalam mempengaruhi keputusan pembelian smartphone merek samsung.

2. Pengaruh Faktor Sosial $\left(\mathrm{X}_{2}\right)$ terhadap keputusan pembelian $(\mathrm{Y})$ secara parsial

Berdasarkan output coefficient uji t, diperoleh nilai signifikan 0,941 lebih besar dari 0,05 yang artinya bahwa faktor sosial $\left(\mathrm{X}_{2}\right)$ berpengaruh positif dan tidak signifikan terhadap keputusan pembeilan smartphone merek Samsung (Y), sehingga Ha ditolak yaitu faktor sosial berpengaruh secara positif dan signifikan terhadap keputusan pembelian smartphone merek Samsung.

Adapun penelitian ilmiah yang dilakukan oleh Rita, dengan judul penelitian, "Pengaruh Faktor-faktor Perilaku Konsumen terhadap Keputusan Pembelian produk Oriflame di Makasar". Penelitian ini menggunakan metode populasi dan sampel. Hasil penelitian menunjukan faktor Sosial yang paling dominan dalam mempengaruhi keputusan pembelian produk Oriflame di Makasar. Hal ini berbanding terbalik dengan hasil penelitian ini yang dimana faktor sosial berpengaruh positif akan tetapi tidak signifikan dalam keputusan pembelian smartphone merek Samsung, hal ini disebabkan oleh banyaknya responden yang memilih netral pada bagian faktor sosial.

Upaya memasukan kategori tengah adalah untuk memfasilitasi yang memiliki trait yang sedang. Menurut Klofer dan Madden menjelaskan bahwa penyediakan alternatif tengah respon bertujuan untuk memberikan kesempatan bagi responden yang memiliki sikap moderat terhadap peenyataan yang diberikan. Sedangkan menurut Cronbach menyediakan kategori tengah memungkinkan responden untuk menunjuk respon yang netral dan lebih diskriminatif dalam respon mereka, membuat nilai skala yang lebih handal dan skala yang lebih disukai oleh responden. Tidak disediakannya alternatif tengah akan menyebabkan 
responden merasa dipaksa untuk memilih secara bipolar. Keterpaksaan ini akan memberikan kontribusi kesalahan sistematis dalam pengukuran.

Beberapa ahli telah meneliti mengapa responden memilih alternatif tengah kategori. Menurut shaw dan Wright mengemukakan tiga kemungkinan responden memilih tiga kategori tengah yaitu :

1. Mereka tidak memiliki sikap atau pendapat.

2. Mereka ingin memberikan penilaian seimbang.

3. Mereka belum memberikan sikap atau pendapat yang jelas.

Menurut penelitian yang dilakukan oleh Daniel Teguh Tri Santoso dan Endang Purwanti dengan judul "pengaruh faktor budaya, faktor sosial, faktor pribadi, dan faktor Psikologi terhadap keputusan pembelian konsumen dalam memilih produk operator seluler indosat IM3 dikecamatan pringapus kabupaten Semarang" hasil penelitian menunjukan bahwa faktor sosial tidak berpengaruh secara signifikan. Hal ini sejalan dengan penelitian ini yang dimana faktor sosial juga tidak berpengaruh secara signifikan, yang di sebabkan kurangnya pengaruh sosial baik itu pengaruh keluarga, teman, ataupun lingkungan mereka sendiri.

3. Pengaruh faktor budaya $\left(X_{1}\right)$ dan faktor sosial $\left(X_{2}\right)$ secara simultan atau bersama-sama terhadap keputusan pembelian smartphone merek Samsung.

Hasil penelitian menunjukan bahwa pengaruh secara bersama-sama (simultan) faktor budaya $\left(\mathrm{X}_{1}\right)$ dan faktor sosial $\left(\mathrm{X}_{2}\right)$ terhadap keputusan pembelian smartphone merek samsung (Y) dengan nilai signifikan sebesar 0,000 lebih kecil dari 0,05 sehingga Ha diterima. Faktor budaya dan faktor sosial berpengaruh positif dan signifikan terhadap keputusan pembelian smartphone merek Samsung karena di uji secara simultan atau bersama-sama dan sama-sama berpengaruh terhadap keputusan pembelian.

Adapun penelitian terdahulu yang dilakukan oleh Rita, dengan judul penelitian "Pengaruh Faktor-faktor Perilaku Konsumen Terhadap Keputusan Pembelian Produk Oriflame di Makasar". Penelitian ini menggunakan metode populasi dan sampel, hasil penelitian menunjukan pengaruh faktor budaya dan sosial seacara simultan atau bersama-sama berpengaruh positif dan signifikan terhadap keputusan pembelian. Hasil penelitian yang dilakukan oleh Rita sejalan dengan penelitian ini, hal ini bisa dilihat dari uji simultan atau bersama-sama yang menunjukan faktor budaya dan faktor sosial berpengaruh secara positif dan signifikan terhadap keputusan pembelian smartphone merek Samsung.

\section{Kesimpulan}

Berdasarkan hasil penelitian yang dilakukan oleh peneliti dengan judul " Analisis pengaruh faktor budaya dan sosial terhadap keputusan pembelian smartphone merek Samsung" maka dapat ditarik kesimpulan sebagai berikut: 
1. Faktor faktor budaya $\left(\mathrm{X}_{1}\right.$ berpengaruh positif dan signifikan terhadap keputusan pembelian smartphone merek Samsung (Y). Dengan mengumpulkan item-item pertanyaan dan melewati beberapa uji faktorfaktor yang mempengaruhi perilaku konsumen.

2. Pengaruh faktor sosial $\left(\mathrm{X}_{2}\right)$ berpengaruh positif dan tidak signifikan terhadap keputusan pembelian smartphone merek Samsung (Y). Dengan mengumpulkan item-item pertanyaan dan melewati beberapa uji dari faktor-faktor yang mempengaruhi perilaku konsumen.

3. Pengaruh faktor budaya $\left(X_{1}\right)$ dan faktor sosial $\left(X_{2}\right)$ secara siemultan berpengaruh positif dan signifikan terhadap keputusan pembelian smartphone merek Samsung. Dengan mengumpulkan item-item pertanyaan dan melewati beberapa uji dari faktor-faktor yang mempengaruhi perilaku konsumen.

\section{Saran}

Dari besarnya nilai koefisien determinasi maupun kontribusi yang diberikan oleh faktor perilaku konsumen yaitu faktor budaya dan sosial terhadap keputusan pembelian menunjukkan bahwa masih diperlukan adanya penelitian lanjutan bagi peneliti lain untuk meneliti variabel lain yang tidak dimasukkan dalam penelitian ini, karena munculnya sebuah perilaku pembelian konsumen merupakan akibat dari banyak faktor antara lain marketing mix (produk, harga, promosi, dan distribusi).

\section{Daftar Pustaka}

Anggito, Albi dan Johan Setiawan, Metodologi Penelitian Kualaitatif, Sukabumi: CV Jejak, 2018.

Darmawan, Deni, Metodologi Penelitian Kuantitatif, Bandung: PT Remaja Rosdakarya, 2013.

Firmansah, M. Anang, perilaku konsumen (sikap dan pemasaran), Yogyakarta: Deepublish, 2018.

Ginting, Nembah F. Hartimbul, manajemen pemsaran, Bandung: Yrama Madya, 2011.

Hartono, Analisis Data Statistika dan Penelitian, Edisi ke 1, Jakarta: Pustaka Pelajar, 2013.

Hamid, Abdul, Pedoman penulisan skripsi, Jakarta: FEIS, 2007.

Kotler, Philip, manajemen pemasaran Edisi ke 11, Jakarta: PT Indeks kelompok Gramdia, 2005.

Kotler, Philip dan Kevin L. K., manejemen pemasaran, Edisi ke 12 PT Macanan Jaya Cermelang, 2007. 
Kotler, Philip dan Kevin L. K., manejemen pemasaran, Edisi ke 13, Jakarta: Erlangga, 2008.

Mangkunegara, Anwar Prabu, Perilaku Konsumen, Edisi Revisi, Bandung: PT Refika Aditama, 2002.

Mowen, Jhon C. dan Michael Minor, perilaku konsumen, Jakarta: Erlangga, 2002.

Mursid, M., manajemen pemasaran, Jakarta: Bumi Akasara, 2015.

Pramesti, Getut, Kupas Tuntas Data Penelitian Dengan SPSS 22, Jakarta: PT Elex Media Komputindo, 2014.

Peter, J. Paul dan Jerry C. Olson, perilaku konsumen dan stategi pemasaran, Edisi ke 4, Jakarta: Erlangga, 1999.

Rahmat, H., Statistika Penelitian, Bandung: Pustaka Setia, 2013.

Sudaryono, Metodologi Penelitian, Jakarta: PT Grafindo Persada, 2017.

Sugiyono, Metode Penelitian Administrasi, Bandung: Alfabeta, 2007.

Sunyoto, Danang, Analisis Regresi dan Korelasi Bivariat, Yogyakarta: Amara Books, 2007.

Tjiptono, Fandy, Stuurategi Pemasaran, Edisi 3, Yogyakarta: ANDI, 2008.

Umar, Husain, Studi Kelayakan Bisnis, Edisi Ke 2, Jakarta: Gramedia Pustaka Utama, 2003.

Walgito, Bimo, Pengantar Psikologi Umum, Yogyakarta: ANDI, 2003.

Agus Tri Haryanto,"Samsung masing menjadi Raja Ponsel di Indonesia”, diakses dari http://m.detik.com/inet/consumer/d-4446865/samsung-masih-rajaponsel-di-indonesia-ini-daftar-5-besarnya tanggal 24 Juli 2019 pada pukul 15.00 WIT.

Hutami Permatasari, skripsi: "pengaruh citra merek, fitur, dan persepsi harga terhadap keputusan pembelian”, Yogyakarta: UMY, 2016.

Julianda, Ikko dan Eka Komalasari, Faktor yang mempengaruhi konsumen dalam pembelian produk smartphone Samsung, Jurnal Valuta Vol. 3 No 1, April 2017.

Muhammad Gifary, skripsi,"faktor-faktor yang mempengaruhi keputusan konsumen dalam pembelian minuman isotonic", Bandar Lampung: Universitas Lampung,2017.

Syafirah, Lisbeth Mananeke, dan jopie Jorie Rotinsulu dengan judul penelitian, Pengaruh Faktor-faktor Perilaku Konsumen Terhadap Keputusan Pembelian Produk Pada Holland Bakeri Manado”, jurnal EMBA Vol. 5 No 2, Juni 2017.

Sunarto,"Analisis Perilaku Konsumen Terhadap Keputusan Pembelian Handphone Xiomi Redmi 3S”, jurnal moneter Vol. V No 1, April 2018.

Rita,Skripsi: "pengaruh faktor-faktor perilaku konsumen terhadap keputusan pembelian produk oriflame”, Makasar:UIN Alauddin,2018. 
Widisudharta, metodologi penelitian, diakses dari https://widisudharta.weebly .com/metode-penelitian-skripsi.html tanggal, 15 Agustus 2019, pukul 11.33 WIT. 